\title{
PUERTO RICO GROUND-WATER QUALITY
}

By Allen Zack, Teresita Rodriguez-Alonso, and Angel Roman-Mas

U.S. Geological Survey Open-File Report 87-0749 


\section{DEPARTMENT OF THE INTERIOR \\ DONALD PAUL HODEL, Secretary}

\section{U.S. GEOLOGICAL SURVEY}

Dallas L. Peck, Director

For additional information:

Chief Hydrologist

U.S. Geological Survey

407 National Center

Reston, VA 22092
For sale by:

U.S. Geological Survey

Books and Open-File Reports Section Federal Center

Box 25425

Denver, Colorado 80225

Use of trade names in this report is for descriptive purposes only and does not constitute endorsement by the U.S. Geological Survey 


\section{FOREWORD}

This report contains summary information on ground-water quality in one of the 50 States, Puerto Rico, the Virgin Islands, or the Trust Territories of the Pacific Islands, Saipan, Guam, and American Samoa. The material is extracted from the manuscript of the 1986 National Water Summary, and with the exception of the illustrations, which will be reproduced in multi-color in the 1986 National Water Summary, the format and content of this report is identical to the State ground-water-quality descriptions to be published in the 1986 National Water Summary. Release of this information before formal publication in the 1986 National Water Summary permits the earliest access by the public. 
Contents

Ground-Water Quality . . . . . . . . . . . . . . . . . . . . . . 1

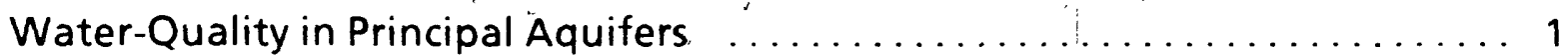

Background Water Quality .......................... 1

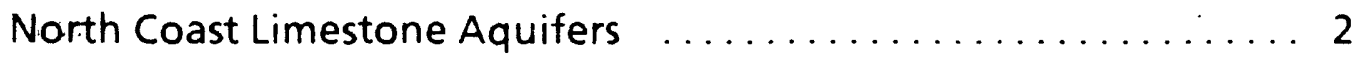

South Coast Plain Alluvial Aquifer .................... 2

East and West Coast Alluvial Valley Aquifers $\ldots \ldots \ldots \ldots \ldots \ldots 2$

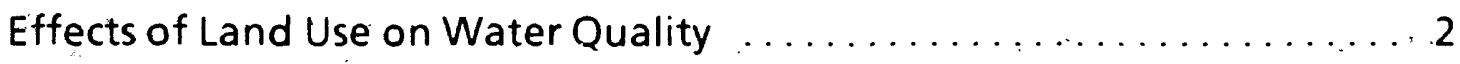

Industrial-Waste Disposal and Accidental Spills $\ldots \ldots \ldots \ldots \ldots .2$

Municipal Landfills ........................... 3

Agricultural-Pesticide Application $\ldots \ldots \ldots \ldots \ldots \ldots \ldots \ldots \ldots$

Large Ground-Water Withdrawals $\ldots \ldots \ldots \ldots \ldots \ldots \ldots \ldots$

Barnyard Waste or Septic Drainage ..................... 3

Potential for Water-Quality Changes $\ldots \ldots \ldots \ldots \ldots \ldots \ldots \ldots \ldots$

Ground-Water-Quality Management ....................... 3

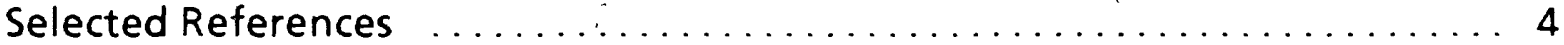

Illustrations

Figure 1.--Selected geographic features and 1980 population distribution in Puerto Rico.

Figure 2.--Principal aquifers and related water-quality data in Puerto Rico. . . 6

Figure 3.--Selected waste sites and ground-water-quality information in

Puerto Rico. ................................ 7

Figure 4.--Areas of ground water containing a dissolved-solids concentration larger than 2,000 milligrams per liter. 


\section{Puerto Rico Ground-Water Quality}

Aquifers in Puerto Rico (fig. 1) provide $170 \mathrm{Mgal} / \mathrm{d}$ (million gallons per day) of freshwater for domestic, industrial, and agricultural uses. Ground water is the source of drinking water for about 900.000 people and for most of the irrigation requirements and the expanding pharmaceutical and electronics industries.

The quality of Puerto Rico's ground water is suitable for most purposes and generally meets the drinking-water standards established by the Puerto Rico Department of Health (PRDOH). However, large water withdrawals from aquifers along the coast have caused seawater encroachment, resulting in well abandonment. Large concentrations of iron and manganese are local problems for users of ground water on the east and west coasts.

The most important aquifers in Puerto Rico (U.S. Geological Survey, 1985, p. 367) occur along the south and north coasts (figs. $2 A, 2 B$ ). The South Coastal Plain alluvial aquifer provides about 50 percent of the total public water supply of the south coast. The North Coast limestone water-table and artesian aquifers provide about 20 percent of the public water supply to north-coast communities. Other aquifers occur in alluvial valleys along the east and west coasts, within the alluvial and volcanic rocks of the interior of the island, and in the Esperanza and Resolucion Valley on the island of Vieques. About 50 percent of the total ground-water withdrawals in Puerto Rico are from the South Coastal Plain alluvial aquifer, 35 percent from the North Coast limestone aquifers, 10 percent from the East and West Coast alluvial valley aquifers, and 5 percent from the alluvial and volcanic rock aquifer of the island interior.

Degradation of water quality from accidental spills of organic chemicals and waste disposal is an increasing problem. Recent investigations by the U.S. Geological Survey have shown that groundwater contamination with volatile, synthetic organic chemicals is intespread (Guzman-Rios and Quinones-Marquez, 1985). The conti....ination has affected the suitability of ground water for public water supply in areas of the north, south, and east coasts.

At present (1986), the U.S. Environmental Protection Agency (EPA) has permitted a total of 362 generators of hazardous waste to operate under the Federal Resource Conservation and Recovery Act (RCRA) of 1976. Eight sites (fig. 3) have been included in the National Priorities List (NPL) of hazardous waste sites and designated as Superfund sites (U.S. Environmental Protection Agency, 1986c).

These sites are currently monitored as part of the Comprehensive

ironmental Response, Compensation, and Liability Act (CERCLA)

1980. Although no ground-water contamination has been detected at any of the RCRA sites, contamination has been confirmed at four

the eight CERCLA (Superfund) sites. However, the chemicals con-

.wating the aquifers have not been linked in all instances to surC releases or specific site contaminants.

Since 1955, the U.S. Geological Survey has monitored und-water quality in cooperation with several agencies of the immonwealth of Puerto Rico. One of the programs included analyses of various organic and inorganic constituents at 243 public water-supply wells. In addition, where ground-water-quality pro'ams are suspected or identified, the Geological Survey has proided technical support to various Commonwealth and Federal rencies in conducting interpretive hydrologic investigations to setermine the extent and severity of contamination and to maintain ippropriate monitoring networks. The Geological Survey assisted the EPA in defining the hydrology of the Vega Alta CERCLA site (fig. $\therefore A$, site $\mathrm{H}$ ) in north-central Puerto Rico. Test wells were drilled and soil and water samples were collected and analyzed to define the horizontal and vertical distribution of contaminants and to determine hydraulic properties of the shallow aquifer and confining beds. Assistance in collecting and interpreting ground-water-quality and geologic data was also provided to the EPA and local agencies at the Barceloneta CERCLA site'(fig. 3A, site $\mathrm{G}$ ).

\section{WATER QUALITY IN PRINCIPAL AOUIFERS $: \because a$}

Ground water throughout Puerto Rico is generally suitable for most uses except near the coast where the aquifer contains saltwater. Puerto Rico has several geochemically' distińct aquifer environments. The North Coast limestone artesian aquifer, consisting of the Cibao Formation and Lares Limestone, contains water geochemically similar to the overlying North Coast limestone watertable aquifer, which consists of the Aymamon "and Âguada limestones and the incised alluvial valleys (fig. 2C). Distinct chemical characteristics have been observed in water from alluvial aquifers in the South Coastal Plain, the West Coast, and the East Coast systems. These regional distinctions in chemical composition of the ground waterare relatéd in part to areal differences in aquifer composition and texture,

Saltwater occurs in all aquififers in Pùerto Ríco ex cept within the interior alluvial and volcanic rock aquifer and the North Coast limestone artesian aquifer. The saltwater commonly underlies freshwater or is kept in hydrodynamic equilibrium laterally by inland freshwater moving outward from the island.

\section{BACKGROUND WATER QUALITY}

Reliable ground-water-chemistry data have been collected since 1955 in Puerto Rico. The largest number of samples was collected from aquifers most intensively developed-the South Coastal Plain alluvial aquifer and the North Coast limestone water-table aquifer. Fewer data are available for the North Coast limestone artesian aquifer, and the East and West Coasts alluvial valley aquifers. Water-quality data are scarce for the alfuvial and-volcantic rock aquifer and the Esperanza and Resolucion Valley aquifer.

The quality of water from all aquifers in Puerto Rico is generally similar. A statistical summary of data from 1955 to 1985 for dissolved solids, hardness (as calcium carbonate), nitrate (as nitrogen), chloride, and sulfate (fig. $2 C$ ) characterizes the small variability in chemical composition of the water. The summary has been compiled from the U.S. Geological Survey's National Water Data Storage and Retrieval System (WATSTORE). Percentiles of the variables are compared to national standards that specify the maximum concentration or level of a contaminant in drinking-water supply as established by the U.S. Environmental Protection Agency $(1986 \mathrm{a}, \mathrm{b})$. The primary maximum contaminant level standards are health related and are legally enforceable. The secondary maximum contaminant level standards apply to esthetic qualities and are recommended guidelines. The primary drinking-water standards include a maximum concentration of $10 \mathrm{mg} / \mathrm{L}$ (milligrams per liter) nitrate (as nitrogen), and the secondary drinking-water standards include maximum concentrations of $500 \mathrm{mg} / \mathrm{L}$ dissolved solids, $250 \mathrm{mg} / \mathrm{L}$ chloride, and $250 \mathrm{mg} / \mathrm{L}$ sulfate.

The water is generally very hard (fig. $2 C$ ), as calcium and bicarbonate are the dominant ions. The calcium and bicarbonate facies is replaced by a sodium chloride facies near the coast in a zone of freshwater-saltwater mixing. 


\section{North Coast Limestone Aquifers}

Dissolved-solids concentrations for the North Coast limestone aquifers-water table and artesian-increase along the hydraulic gradient. Dissolved-solids concentrations can be larger than $500 \mathrm{mg} / \mathrm{L}$ in areas of saltwater intrusion or encroachment near the coast. Suitability of water for irrigation and public water supply is affected within these areas. The North Coast limestone artesian aquifer has dissolved-solids concentrations smaller than $500 \mathrm{mg} / \mathrm{L}$ throughout the aquifer. The freshwater-saltwater interface of the North Coast limestone artesian aquifer probably is seaward and freshwater discharges directly at the seabed.

Calcium and bicarbonate are the dominant ions within the artesian aquifer and the freshwater parts of the water-table aquifer, because they are derived from the aquifer matrix (Roman-Mas and Lee, 1985). The calcium bicarbonate facies is replaced by a sodium chloride facies in areas of the water-table aquifer where saltwater intrusion occurs. Chloride concentrations can be as large as 1,900 $\mathrm{mg} / \mathrm{L}$

Background concentrations of nitrate for the water-table and artesian aquifers are smaller than the detection limit. Sulfate concentrations are usually small as the sulfate source within these aquifers is gypsum, a relatively uncommon mineral.

\section{South Coastal Plain Alluvial Aquifer}

Dissolved-solids concentrations throughout the South Coastal Plain alluvial aquifer are relatively large (fig. $2 C$ ), ranging from 130 to $1,750 \mathrm{mg} / \mathrm{L}$. Calcium and bicarbonate are the predominant ions; these ions originate from beach and reef deposits that were buried by sediments eroded from the interior igneous rocks during the last, rise in sea level (Fernando Gomez-Gomez, U.S. Geological Survey, written commun., 1986). Near the coast, where large dissolved-solids concentrations are derived from saltwater intrusion or encroachment, and sodium and chloride become the predominant ions.

Relatively large nitrate concentrations are observed within the South Coastal Plain alluvial aquifer; nevertheless, observed concentrations generally do not exceed the primary drinking-water standard. Because of the presence of relatively soluble and finely disseminated pyrite within the South Coastal Plain alluvial aquifer. sulfate concentrations are generally larger than in the North Coast limestone aquifers.

\section{East and West Coastal Alluvial Valley Aquifers}

Chemical composition and evolution of water within the East and West Coast alluvial aquifers are similar to those in the North and South Coast aquifers. However, dissolved-solids concentrations are larger: as much as 4,270 and $10,000 \mathrm{mg} / \mathrm{L}$ within the East and West Coast alluvial aquifers, respectively. Chloride concentrations also are relatively large, reaching 1,700 and $5,800 \mathrm{mg} / \mathrm{L}$ in the East and West Coast alluvial aquifers, respectively. These large dissolved-solids and chloride concentrations indicate significant saltwater encroachment within these aquifers, particularly the West Coast alluvial aquifer, in comparison to the North and South Coast aquifers.

Nitrate concentrations are generally small, with median concentrations of $0.4 \mathrm{mg} / \mathrm{L}$ (aquifer 4 ) and $0.6 \mathrm{mg} / \mathrm{L}$ (aquifer 5 ). However, in some areas of the West Coast alluvial aquifer, nitrate concentrations may exceed drinking-water standards.

Sulfate concentrations within the West Coast alluvial aquifer are considerably larger than for the other aquifers. The median sulfate concentration is $64 \mathrm{mg} / \mathrm{L}$; however, about 25 percent of the compiled analyses exceeded the secondary drinking-water standard.

Areas of naturally impaired water quality have been found within the East Coast alluvial aquifer (fig. $3 B$ ). Large concentrations of iron and manganese, derived from plutonic rocks and an- cient swamp deposits, have been reported for many wells in the area (Anders, 1971; Adolphson and others, 1977; Robert Graves, U.S. Geological Survey, written commun,, 1986). Concentrations of iron and manganese can be as large as 2.4 and $6.2 \mathrm{mg} / \mathrm{L}$, respectively, but do not affect the suitability of g1 ound water for irrigation and livestock - the primary uses of ground water in these areas. However, the large concentrations are objection ble because they can clog pipes, produce unpleasant taste and stain plumbing fixtures as well as clothes during laundering.

The Puerto Rico Aqueduct and Sewer Authority (PRASA) has recently reported concentrations of selenium larger than EPA recommended maximum level of $0.01 \mathrm{mg} / \mathrm{L}$ in four wells drilled in the volcanic rock of the south and west coasts of the island (Nicolino Liberatore, Puerto Rico Aqueduct and Sewer Authority, written commun., 1986). Two of the wells located at Guayanilla and one at Cabo Rojo were intended for public water supply, but were not used after selenium concentrations as large as $9.10 \mathrm{mg} / \mathrm{L}$ were reported.

Until 1978, the Esperanza and Resolucion Valley aquifer was the only source of freshwater for the population of the island of Vieques. Most wells completed in this aquifer in the Esperanza Valley were affected by sea-water encroachment when ground-water withdrawals exceeded 400,000 gallons per day (Sigfredo Torres, U.S. Geological Survey, oral commun., 1986). Chloride concentration in water withdrawn from several public-supply wells became as large as $500 \mathrm{mg} / \mathrm{L}$. Ground-water withdrawals from the Esperanza Valley well field were discontinued in 1978 when a pipeline for public water supply was installed from the east coast of Puerto Rico. By 1981 , the seawater drawn into the aquifer by intensive pumping was pushed seaward by rainfall recharge. The aquifer currently (1986) has reverted to its original pre-pumpirg condition, with chloride concentrations of $90 \mathrm{mg} / \mathrm{L}$ or less:

\section{EFFECTS OF LAND USE ON WATER Quality}

Ground-water quality has been degraded in parts of several principal aquifers in Puerto Rico. Investigations by the U.S. Geological Survey and interpretation of data collected as part of the cooperative monitoring program have documented widespread aquifer contamination in Puerto Rico (Guzman-Rios and QuinonesMarquez, 1985; Guzman-Rios and others, 1986). Contamination has been caused by industrial-waste disposal and accidental spills. municipal landfills, agricultural-pesticide application, large groundwater withdrawals for urban centers and irrigation, and barnyard waste or septic drainage.

\section{Industrial-Waste Disposal and Accidental Spills}

The most serious threat to the continued use of aquifers as a source of drinking water in Puerto Rico is the contamination of ground water by various synthetic volatile organic chemicals (vOC). These chemicals are used as industrial solvents, degreasers, and cleaning agents, or are generated as toxic byproducts from metal, electronic, and pharmaceutical industries. Trichloroethylene (TCE) and tetrachloroethylene (PCE) have been identified as the principal organic contaminants. Concentrations of TCE and PCE as large as 480 and $776 \mu \mathrm{g} / \mathrm{L}$ (micrograms per liter), respectively, were measured during a study in which 243 public water-supply wells were sampled throughout the island (Guzman-Rios and QuinonesMarquez, 1984; 1985). The PRDOH has established an enforceable limit of $50 \mu \mathrm{g} / \mathrm{L}$ for TCE or PCE, and $100 \mu \mathrm{g} / \mathrm{L}$ for total vOC. The PRASA has discontinued use of 13 public water-supply wells with a combined production of $5.5 \mathrm{Mgal} / \mathrm{d}$ because of increased concentrations of voC (fig. $3 B$ ).

Waste-disposal wells have contributed to ground-water contamination. In 1969, about 40 waste-disposal wells were operating in Puerto Rico. Wastes injected through wells included sewage, oil, neutralized acid, organic compounds, dyes, pickling liquors, 
pineapple cannery wastes?'and brewery wastes (Donald Jordan. U.S. Geological Survey; written commun., 1969). In all known instances, the.wastes were injected into North Coast timestone aquifers, both the water table and the artesian. At present (1986), the-injection of any waste, except cooling waters; is prohibited.

Five waste-disposal sites in Puerto Rico have been designated as CERCLA (Superfund) sites (fig: $3 A$; Sites A: C, D, E.' and F). Hazardous wastes disposed at these sites include pharmaceutical wastes, mercury pesticides, mercury from thermometer and lightswitch manufacturing, chromium, itron, and selenium:

There are 362 generators of hazardous wastes in Puerto Rico operating under RCRA, of which about 73 (fig. $3 A$ ) are facilities for treatment, storage: and disposal (L.J. Livingston. U.S. Environmental Protection Agency. Region II. written commun.. 1986). The remaining 289 sites temporarily store the waste'at their industrial facilities for later removal to a permanent storage site or for transport to the United States. At present (1986). only one operating commercial industrial landfill in Puerto Rico is used for storing hazardous waste and toxic byproducts. It is near Tallaboa on the sauth coast and reportedly accounts for 10 percent of all industrial hazardous waste produced in the island (Carl-Axel Soderberg. Puerto Rico Environmental Quality Board, oral çommun., 1986). The Puerto Rico Environmental Quality Board (PREQB) estimates that more than 500.000 tons per year of hazardous wastes are produced in Puerto Rico, of which 40 percent is shipped to the United States (Carl-Axel Soderberg, Puerto Rico Environmental Quality Board, oral commuñ., 1986).

As of Soptember 1985, 18 hazardous-waste sites at 2 facilities in Puerto Rico had been identified by the U.S. Department of Defense (DOD) as part of their Installation Restoration Program (IRP) as having potential for contamination (U.S. Department of Defense. 1986). The IRP, established in 1976, parallels the EP4 Superfund program under CERCLA. EPA presently ranks these sites under the hazard ranking system and may include them in the NPL.

During September 1982, 15.000 gallons of carbon tetrachloride was accidentally spilled in the Barceloneta area. Laboratory analyses of water samples collected after the spill indicated concentrations of carbon tetrachloride as large as $5 \mathrm{mg} / \mathrm{L}$. The spill resulted in the closing of two industrial. one domestic. and three public water-supply wells. About 10,000 persons, who obtained their drinking water from those wells. were affected. The area was designated as a CERCLA site by the EPA (fig. $3 A$. Site G).

\section{Municipal Landfills}

Seventy-four municipal landfills throughout Puerto Rico (fig. $3 C$ ) are used for the disposat of non-hazardous wastes. In 1977. the U.S. Geological Survey conducted a reconnaissance study of 50 selected solid-waste disposal sites in Puerto Rico (TorresGonzalez and Gomez-Gomez, 1982, p. 7) to determine the potential for ground-water contamination by the percolation of leachate. In many of the locations, the cover material was relatively permeable and offered insignificant resistance to infiltration of the leachate. Although aquifer contamination has not been the subject of any studies, 25 sites showed potential for leachate percolation. Further investigation is needed to determine contamination potential at other waste-disposal sites. Open-burning dumps are no longer allowed in Puerto Rico. Six known former open-burning dump sites are shown in fig. $3 A$ as "other."

\section{Agricultural-Pesticide Application}

Preliminary tests have detected pesticides and pesticide residues in several wells in aquifers, both on the north and on the south coasts of Puerto Rico (Quinones $=$ Marquez and Alicea-Orfiz, 1985). Large' quantities of pesticieles, including dieldrin dichlorodiphenyl trichloroethane (DDT), were used in Puertô Rico for many years, primarily on sugarcane plantations. These synthetic organic pollutants can affect, groung-water quality at any time in unpredictable ways. because the migration rate of these contaninants through the soil and into the water table in Puerto Rica is unknown.

\section{Large Ground-Water Withdrawals} as a

Large, withdrawals for urban centers and irrigation along coastal areas of Puertorico have indirectly affected the quality. of ground water on a local scale. Between 1960 and 1980 the poptilafion increased by 36 percent, with the largest increases. being within the principal coastal urban areas. Large ground-water withdrawals have induced saltwater encroachment and upconing to pumping centers: In addition, expanding urbanization has covered large parts of aquifer-pecharge areas with relatively impermeable structures, thereby decreasing aquifer recharge from rainfall infiltration. As a result, the freshwater-saltwater interface has moved inland:-Several large irrigation wells located between Arecibo and Marfati on the north coast of Puerto Rico have experienced upconing of saltwater after periods of intensive,pumping. Rice crops have been damaged on occasion by the applied water.

Information is being collected continuously by the'U.S. Geological Survey to determine the islandwide extent of saltwater encroachment. Areas of dissolved concentrations greater than 2,000 $\mathrm{mg} / \mathrm{L}$ are shown in figure 4

\section{Barnyard Waste ồ Septic Drainage}

Increased levels of nitwate (as lurge as $72 \mathrm{mg} / \mathrm{L}$ às nitrogen) have been documented in watersamples withdrawn principally from the South Coastal Plaim alluvial aquifer: Large nitrate concentrations are generally associated wivth shallow water-table conditions. where wastes from animal feedlots. ieptic drainage. or surface contamination have percolated to an aquiter. Fertilizer application in areas of the south coast where the water table is near the land surface may be the source of large nitrate concentrations in the ground water (Carl-Axel Soderbery. Puerto Rico Environmental Quality Board, written commun.. 1986).

\section{POTENTIAL FOR WATER-Quality Changes}

Recent estimates by the Puerto Rico Planning Board (PRPB) indicate that the population of Puerto Rico will reach ahout 4 million in the year 2010 (Quinones-Marquez and Alicea-Ortiz. 1985). The population increase and the associated demand for empioyment will undoubtedly cause further industrial development. which. will place additional demands on the ground-water resourçes. The Puerto Rico Aqueduct and Sewer Authority wili continue to develop groundwater resources to provide drinking-water supplies for rural areas. Further development of the alluvial aquifers near the coast will require careful planning to avoid saltwater encroachment.

Agricultural development is declining in Puerto Rico. However, use of large volumes of tertilizers and pesticides provides a potential source of contamination of the water-table aquifer.

To date (1986). the North Coast limestone artesian aquifer has been free of contamination except where wastes were directly injected by disposal wells into the aquifer. Although subsurface injection has been discontinued. some residual contamination probably remains.

\section{GROUND-WATER-QUALITY MANAGEMENT}

The management of ground-water quality in Puerto Rico is shared by several lobal agencies and the EPA. The Puerto Rico Department of Natural Resourcés (PRDNR) is responsible for planning and regulating the use, improvement. conservation, and development of the water resources of Puerto Rico (Water Law, No. 136 of June 3, 1976). In September 1984, the Department published regulation's that included the management of ground water. 
The most important sections of the regulations include: (1) a system of permits for drilling wells and a franchise to use the ground water, (2) authorizaticial to designate "critical" areas where the groundwater resources could be affected by excessive.demand or contamination, and (3) a system of permits to regulate the quantity of fluids recharged into the aquifers.

At the Federal level, the EPA is the principal agency responsible for the use and management of ground water. The EPA delegates to local agencies the implementation of some of its programs and regulations such as the Safe Drinking Water Act of 1974 and the Pesticide Control Act. The PREQB is responsible for the regulation of industrial, domestic, and agricultural discharges under the Clean Water Act of 1977. The Board similarily manages the Underground Injection Control Program defined by the Safe Drinking Water Act of 1974. In 1985, the Board published extensive regulations for the control of fluids injected into aquifers. This agency has developed regulations to control discharges into sinkholes and the construction and operation of underground storage tanks.

The EPA has delegated the regulation of pesticides that may contaminate ground water (Pesticide Control Act) to the Puerto Rico Department of Agriculture (PRDOA). The PRDOH has been granted primacy by the EPA to oversee the drinking-water program in Puerto Rico. The PRDOH is responsible for the Safe Drinking Water Act of 1974 as regards the quality of drinking water. This agency has implemented a set of regulations that establishes maximum concentrations of ions and chemical compounds permissible in drinking water. The Department relies on the Puerto Rico Aqueduct and Sewer Authority to conduct quality-assurance monitoring for their public-supply wells.

Other Federal laws related to the conservation of ground water have not been delegated by the EPA to Commonwealth agencies. The EPA administers the Resource Conservation and Recovery Act (RCRA), which regulates the management of solid and liquid waste materials; it also manages the Toxic Materials Act of 1976. which controls the production and disposal of toxic materials, as well as CERCLA or Superfund law of 1980. The CERCLA legislation authorizes the Federal government to respond directly to releases (or threatened releases) of hazardous substances and contaminants that may endanger public health or welfare,

Although the EPA has delegated most of the responsibility for the administration of the ground-water-quality management laws to Commonwealth agencies, it still is actively involved in environmental programs that affect ground water. The EPA, through the PREQB, directs its efforts toward programs that regulate the design, construction, and operation of municipal landfills, underground storage tanks, and discharge pools.

Landfills and underground storage tanks constitute potential sources of contamination to aquifers. In Puerto Rico, nearly 50 landfills are located over aquifers that provide drinking water to municipalities. The new regulations will require continuous monitoring and cleaning of those landfills that contain dangerous contaminants. Since 1985, the PREQB has issued orders against 11 service stations for gasoline spills from underground storage tanks.

\section{SELECTED REFERENCES}

Adolphson, D.C., Seijo, M.A., and Robison, T.M., 1977, Water resources of the Maunabo valley, Puerto Rico: U.S. Geological Survey WaterResources Investigations 76-115, 44, p.

Anders R:B., 1971, Electric analog model study of water in the Yabucoa valley, Puerto Rico (Phase-1, Collecting preliminary data and assembling available data): U.S. Geological Survey Open-File Report (unnumbered), $47 \mathrm{p}$.

Giusti, E.V., 1978, Hydrogeology of the karst of Puerto Rico: U.S. Geological Survey Professional Paper 1012, 68 p.

Gomez-Gomez, Fernando. and Heisel, J.E., 1980, Summary appraisals of the Nation's ground-water resources-Caribbean Region: U.S. Geological Survey Water-Supply Paper 813-U, 32 p.

Guzman-Rios, Senen, Garcia, Rene, and Aviles, Ada, 1986, Reconnaissance of volatile synthetic organic chemicals at public-water supply wells throughout Puerto Rico, November 1984-May 1985: U.S. Geological Survey Open-File Report 86-63, 1 p.

Guzman-Rios. Senen. and Quinones-Marquez, Ferdinand, 1984. Groundwater quality at selected sites throughout Puerto Rico. September 1982-July 1983: U.S. Geological Survey Open-File Report 84-058. $1 \mathrm{p}$.

1985, Reconnaissance of trace organic compounds in ground water throughout Puerto Rico. October 1983: U.S. Geological Survey OpenFile Report 84-810, 1 p.

Quinones-Marquez, Ferdinand, and Alicea-Ortiz, Jose, 1985, Agua subterranea en Puerto Rico: U.S. Geological Survey Open-File Report $85-642,6 p$

Roman-Mas. Angel, and Lee, R.W., 1985. Water quality and chemical evolution of ground water within the North Coast limestone aquifers of Puerto Rico: Symposium on Tropical Hydrology and 2nd Caribbean Islands Water Resources Congress 1985. American Water Resources Association Technical Publication Series TPS-85-1, p. $57-63$.

Torres-Gonzalez, Arturo, and Gomez-Gomez, Fernando, 1982 , Geohydrologic descriptions of selected solid waste disposal sites in Puerto Rico: U.S. Geological Survey Open-File Report 81-490, 146 p.

U.S. Department of Defense, 1986. Status of the Department of Defense Installation Restoration Program-Information Paper: Washington, D.C. . U.S. Department of Defense. Office of the Assistant Secretary of Defense (Acquisition and Logistics), Environmental Policy Directorate, February, $35 \mathrm{p}$.

U.S. Environmental Protection Agency, 1986a. Maximum contaminant levels (subpart B of Part 141. National interim primary drinking-water regulations): U.S. Code of Federal Regulations, Title 40, Parts 100 to 149 , revised as of July 1. 1986, p. 524-528.

1986b. Secondary maximum contaminant levels (section 143.3 of part 143. National secondary drinking-water regulations): U.S. Code of Federal Regulations. Title 40, parts 100 to 149 , revised July I, 1986, p. $587-590$

1986c. Amendment to National Oil and Hazardous Substances Contingency Plan; national priorities list, final rule and proposed rule: Federal Register, v. 51. no. 111, June 10, 1986, p. 21053-21112.

U.S. Geological Survey, 1985, National water summary 1984-Hydrologic events, selected water quality trends, and ground-water resources: U.S. Geological Survey Water-Supply Paper 2275, 467 p. 


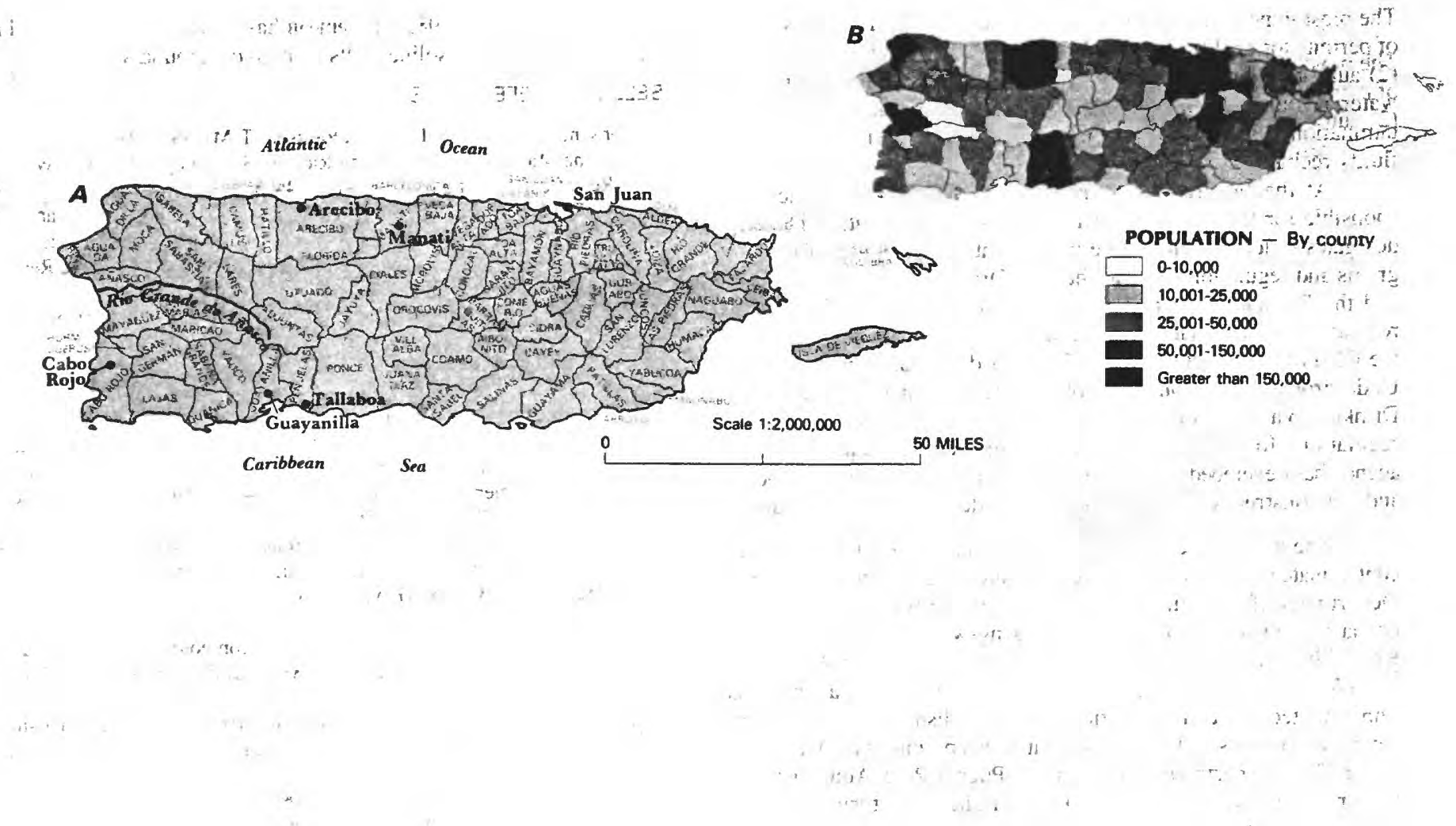

Figure 1. Selected geographic features and 1980 population distribution in Puerto Rico. A, Counties and selected cities. B, Population distribution, as of 1980. (Sources: B, Data from U.S. Bureau of the Census data for county populations.) 
PRINCIPAL AQUIFERS - Numeral is aquifer. number in figure $2 \mathrm{C}$ North Coast limestone water-table (1)

North Coast limestone anesian (2)

South Coastal Plain alluvial (3)

East Coast alluvial valley (4)

West Coast alluvial valley (5)

Alluvial and volcanic rock

Esperanzasand Resolución Valley

A-A' Trace of hydrogeologic section - Horizontal scale of section $2 X$ map seale

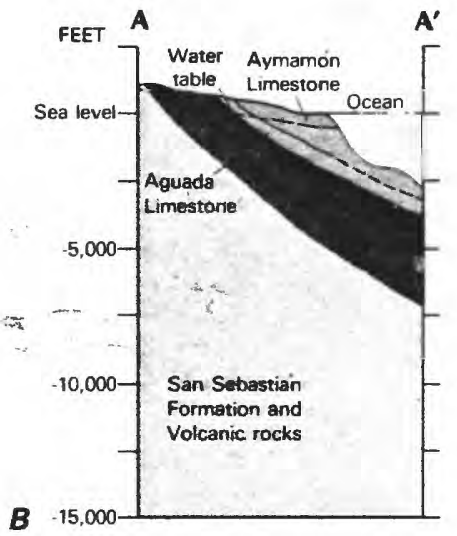

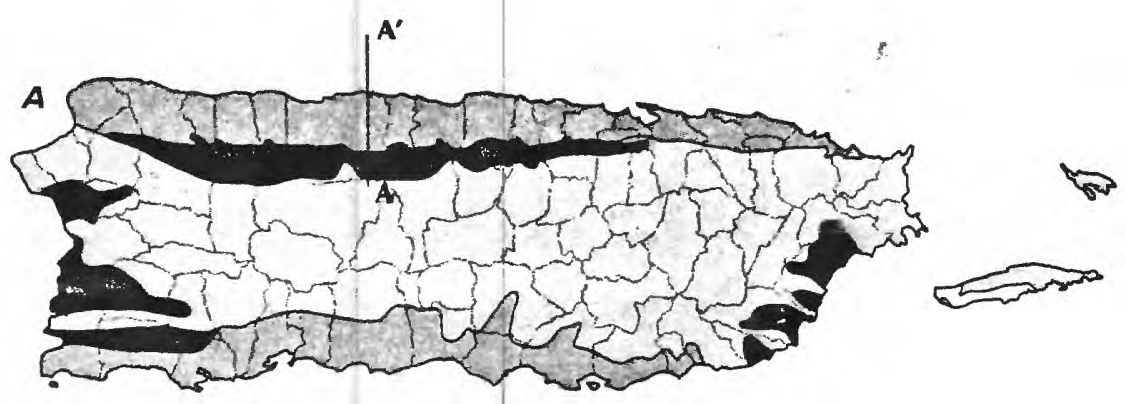

c WATER-QUALITY DATA

Percentile - Percentage of analyses equal to or less than indicated values

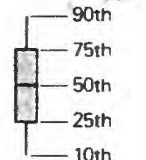

National drinking water standards Maxımum permissible contaminant level (primary)

- - - Maximum recommended contaminant level (secondary)

Reporting limit

Minimum reporting level with analytical method used

NUMBER OF ANALYSES

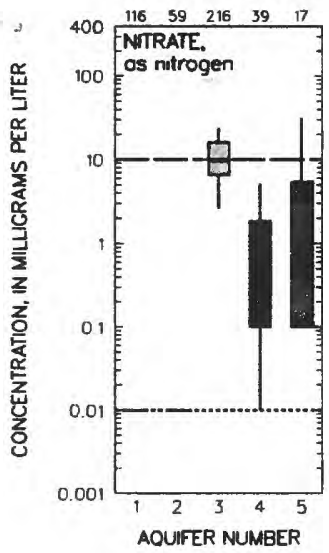

NUMBER OF ANALYSES

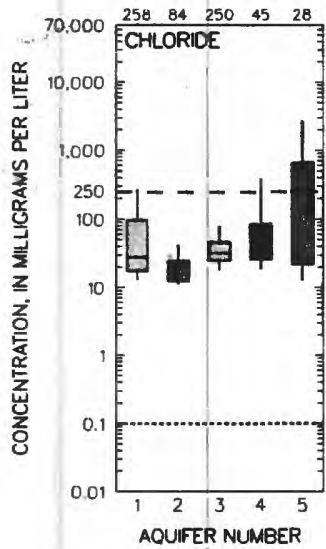

NUMBER OF ANAIYSES
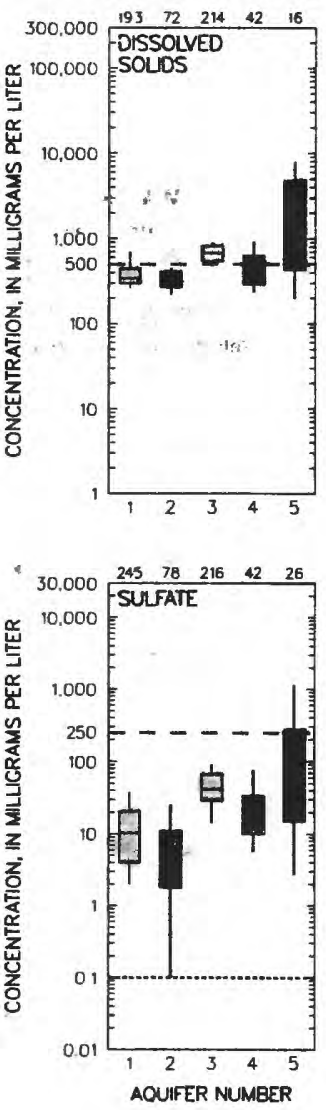

Figure 2. Principal aquifers and related water-quality data in Puerto Rico. A, Principal aquifers. B, Generalized hydrogeologic section. $C$, Selected water-quality constituents and properties, as of 1955-85. (Sources: $A$, Adapted from Gomez-Gomez and Heisel, 1980. B, Adapted from Giusti, 1978. C, Analyses compiled from U.S. Geological Survey files; national drinking-water standards from U.S. Environmental Protection Agency, 1986 a,b.) 


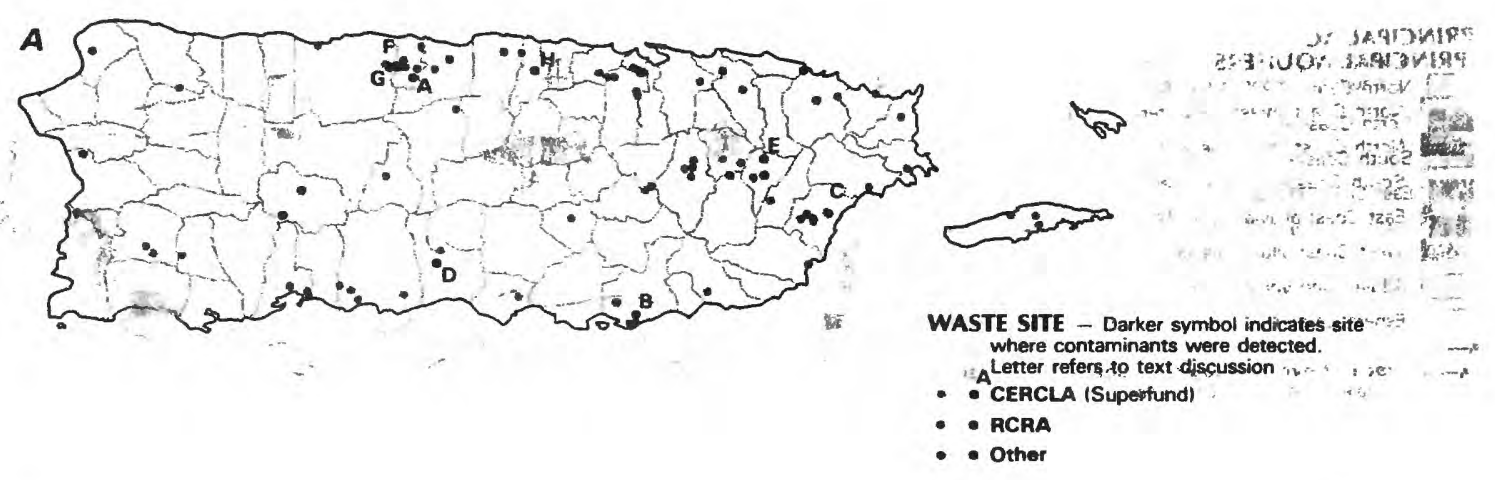

\section{GROUND-WATER QUALITY}

Area of water-quality concern

Naturally impaired water quality other than salt-water intrusion

EZ Human-induced contamination

- Wall that yieids contaminated watar
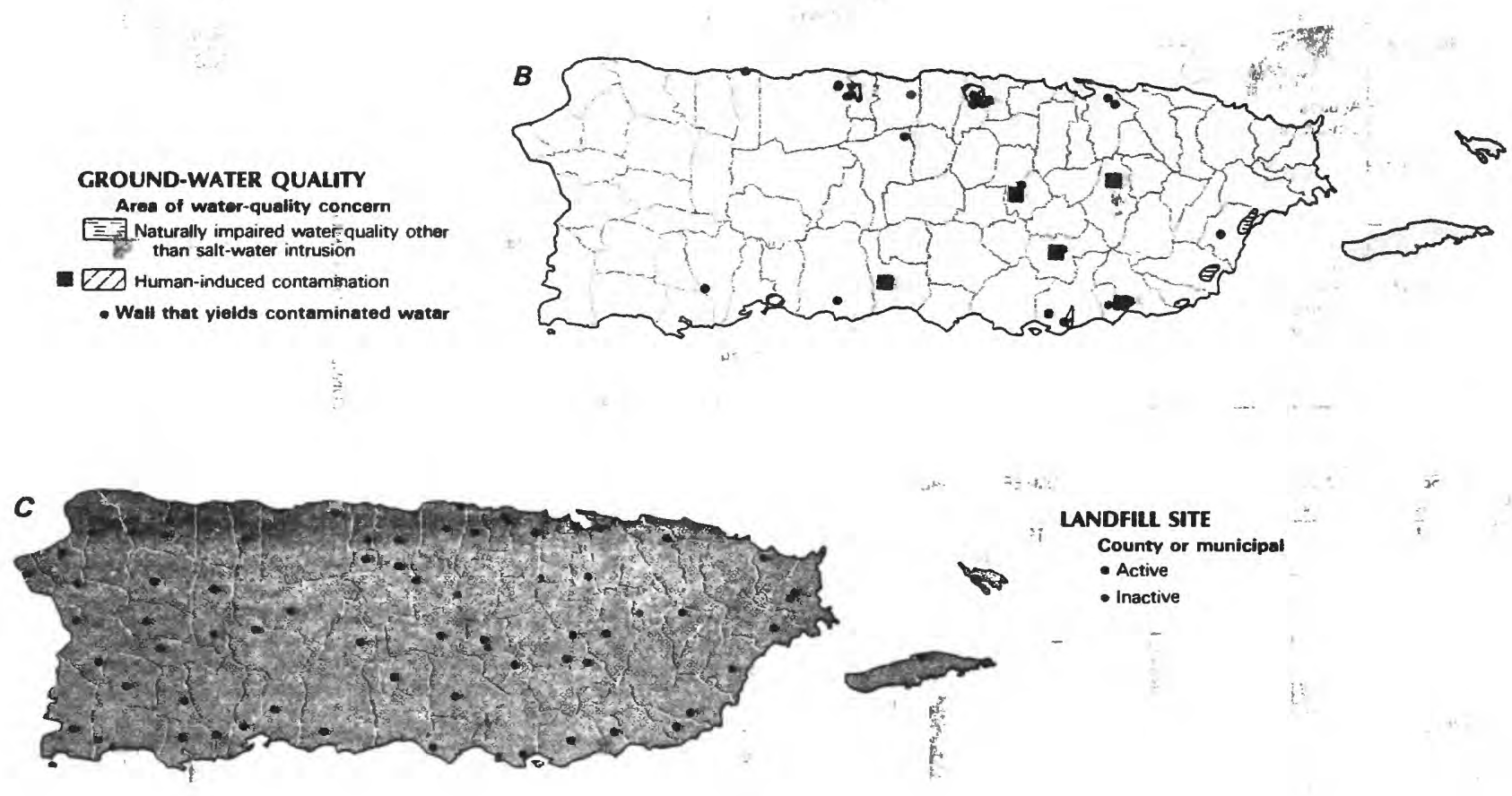

Figure 3. Selected waste sites and ground-water-quality information in Puerto Rico. A, Comprehensive Environmentat-Response, Compensation, and Liability Act (CERCLA) sites; Resource Conservation and Recovery Act (RCRA) sites; and other selected waste sites, as of 1986. B, Areas of naturally impaired water quality, areas of human-induced contamination, and distribution of wells that vield contaminated water, as of 1986. C. Municipal landfills, as of 1986. (Sources: A, Laura J. Livingston, U.S. Environmental Protection Agency, Region II, written commun., 1986; Victor Mata, Puerto Rico Environmental Quality Board, written commun., 1986. B, Guzman-Rios and others, 1986; Guzman-Rios and Quinones-Marquez, 1984; 1985. C. Vicior Mata, Puerto Rico Environmental Quality Board files.) 


\section{EXPLANATION}

Dissolved solids concentration larger than 2000 milligrams per liter

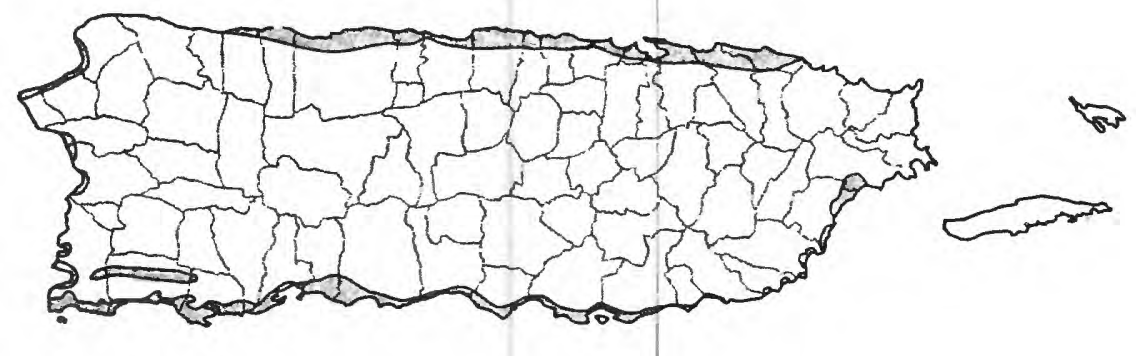

Figure 4. Areas of ground water containing a dissolved-solids concentration larger than 2,000 milligrams per liter. (Source: Modified from Romas-Mas and Lee, 1985; Gomez-Gomez and Heizel, 1980; Robert Graves, U.S. Geological Survey, written commun., 1986.) 